\title{
Reproductive cycles in Bufo mauritanicus (Schlegel, 1841) in a wet area of Beni-Belaïd (Jijel, Algeria)
}

\author{
Omar Kisserli ${ }^{1}$, Salaheddine Doumandji², Jean-Marie Exbrayat ${ }^{3, *}$ \\ ${ }^{1}$ Laboratoire de Pharmacologie et Phytochimie, Faculté des Sciences, Université de Jijel, Ouled Aissa, Jijel, Algeria. \\ ${ }^{2}$ Laboratoire de Zoologie Agricole et Forestière, Institut National Agronomique. El - Harrach, Alger, Algeria. \\ ${ }^{3}$ Université de Lyon, Laboratoire de Biologie Générale, Université Catholique de Lyon et Reproduction et Développement Comparé, Ecole \\ Pratique des Hautes Etudes, Lyon, France. \\ * Correspondence: Université de Lyon. UMRS 449. Biologie Générale, Université Catholique de Lyon, Reproduction et \\ Développement Comparé, EPHE 25 rue du Plat, F-69288 Lyon Cedex 02, France. Phone: +33 472325036, Fax: +33 472325066 \\ E-mail: jmexbrayat@univ-catholyon.fr
}

Received: 1 February 2011; received in revised form: 1 July 2011; accepted: 17 July 2011.

Bufo mauritanicus is an anuran amphibian living in North Africa. Reproductive cycles of this species are not well known, especially in populations living in Algeria. This study is devoted to the knowledge of the reproductive cycle in a population living in the wet area of Beni Belaïd, under a Mediterranean climate characterized by two rainy seasons, January until May and September until December. The examination of the gonads of both sexes allowed us to describe continuous cycles in males and females.

Key words: Bufo mauritanicus; reproduction; sexual cycle.

El ciclo reproductor de Bufo mauritanicus (Schlegel, 1841) en el humedal de Beni-Belaïd (Jijel, Algeria). Bufo mauritanicus es un anuro que habita en el Norte de África. Los ciclos reproductivos de esta especie han sido poco investigados, especialmente en lo que se refiere a las poblaciones de Argelia. Este estudio profundiza en el conocimiento del ciclo reproductor de una población de $B$. mauritanicus en la zona húmeda de Beni Belaïd, en Argelia, caracterizada por un clima mediterráneo con dos estaciones lluviosas, de enero a mayo y de septiembre a diciembre. El estudio de las gónadas de los dos sexos nos ha permitido describir la existencia de ciclos reproductivos continuos tanto en machos como en hembras.

Key words: Bufo mauritanicus; ciclo sexual; reproducción.

Reproductive cycles of amphibians have been studied in many species (NEYRAND DE LEFFEMBERG \& EXBRAYAT, 1995; EXBRAYAT et al., 1998) although in general sexual cycles have been more investigated in males than in females. The reproductive cycles of African species are rather little known. For example, some studies detected continuous annual cycles in several species (Bufo regularis, Ptychadena maccarthyensis, P. oxyrhynchus, Phrynobatrachus calcaratus, Xenopus laevis; DeLsOl et al., 1980, 1981，1995; GUEYDAN-BACONNIER，1980;
Gueydan-BaCONNIER et al., 1984a,b; Pujol, 1985; Pujol \& Exbrayat, 1996, 2000, 2001; EXBRAYAT et al., 1998; Du PREEZ et al., 2005; VAN WYK et al., 2005). On the other side, discontinuous male and female cycles of reproduction have also been described in the viviparous Nectophrynoides occidentalis and other related species (LamotTe \& TuchmanDUPLESSIS, 1948; LAMOTTE et al., 1964, GaVaud, 1976, 1977; XaVIer, 1986).

Bufo mauritanicus is a nocturnal anuran endemic to North Africa, and it is found all 
across the Maghreb, including Algeria, Morocco, and Tunisia (BONS \& GenIEZ, 1996; SCHLEICH et al., 1996). Despite its wide distribution and relative abundance, few works have been devoted to the biology of $B$. mauritanicus, including a review in SCHLEICH et al. (1996) and a study by GuILlon et al. (2004) quoting data related to various ecological aspects, and where the rarity of $B$. mauritanicus in semi-arid areas of Morocco was remarked. The reproductive onset of this species depends greatly on the local conditions (SCHLEICH et al., 1996). KisSERLI \& EXBRAYAT (2006) reported preliminary data about the male reproductive cycle in this species. In males, sexual cycle is continuous with an increase in the number of spermatozoa in August, and a minimum in April, just after the breeding period, revealed by the presence of fertilized eggs in the field (KISSERLI \& EXBRAYAT, 2006). However, information regarding female reproductive cycles is still lacking. The aim of the present work was to analyse in detail the reproductive cycle and variations in the gonadal tissues of both male and female $B$. mauritanicus along the year and its relationships to environmental factors, namely precipitation. The analysis of hormones present during folliculogenesis was also investigated in order to understand hormonal regulation of female reproductive features.

\section{Materials AND METHODS}

The studied animals were randomly captured in the wet area of Beni-Belaid (Jijel, Algeria) throughout the year. This area is limited by the Mediterranean Sea in its northern part, by an agricultural area in its southern part, by Oued El-Kebir to the West and by Zhour Oued and pond areas to the East. Altitude in this locality varies from 0 to $10 \mathrm{~m}$ above sea level. This area is submitted to two rainy seasons, one from January until May and other from September until December, and one dry season, from June until August. In total, 12 males and 27 females were collected across the year as follows: three males and 11 females during the wet season between January and May; four males and eight females during the dry season (between June and August) and five males and eight females during the wet season between September and December. This limited sampling did not threaten the population studied.

Animals were euthanized with tricaine mesylate (MS 222). Sexual organs were immediately fixated with $10 \%$ formalin after dissection. Left gonads were included with paraffin, cut in 5 to $7 \mu \mathrm{m}$ thick sections using a micrometer and stained with the Romeis's azan according to Exbrayat (2001).

Histochemical stainings were used to characterize the chemical composition of tissues. For that, frozen sections of gonads $(14 \mu \mathrm{m}$ thick) were stained with Sudan black in order to detect lipids (MARTOJA \& MARTOJA, 1967). Additional paraffin sections were also stained with Periodic Acid Schiff (PAS) and alcian blue-PAS in order to detect the presence of neutral and acidic carbohydrates according to Martoja \& Martoja (1967).

The detection of $17-\beta$ estradiol in ovaries was performed using immunohistochemical techniques. For that, sections were first incubated with $\mathrm{H}_{2} \mathrm{O}_{2}$ (Fluka, Buchs, Switzerland) in order to eliminate endogenous peroxidases, and then with bovine serum albumin (Sigma, St. Louis, Missouri, USA) to eliminate non-specific reactions. After this, a spe- 
cific antibody directed against $17-\beta$ estradiol (Euromedex, Souffelweyersheim, France) was applied on the sections. After rinsing, immunoreactions were visualized with a streptavidin-biotin amplification test (Kit LSAB 2, Dako, Glostrup, Denmark) using amino ethyl carbazole (AEC) as a chromogen. Presence of hormone was labelled by a red precipitate. Controls were performed by deleting the first antibody. The observation of adjacent tissues was used as internal controls.

\section{RESULTS}

The histological examination of the sections of testis revealed the presence of all the cellular categories of spermatogenesis throughout the year (Fig. 1a). The spermatozoa were anchored in Sertoli cells, ready to be released in the light of the seminiferous tube. Presence of lipids was detected in Leydig-like cells (Fig. 1b).

The folliculogenic dynamic was described in ovaries. Seven stages have been found (stages Ia, Ib, II, III, IVa, IVb, V). Stages IVa an $\mathrm{IVb}$ were the vitellogenic stages at which the oocyte was increasingly filled with yolk platelets (Figs. 2a,b). Stage V was the final stage of maturation at which ovulation can occur. In addition, several atretic follicles were observed. In each stage, the oocyte was surrounded with a more or less thick vitelline membrane that was PAS positive showing the presence of mucopolysaccharides (Fig. 2c). Presence of lipids was detected in the cortical part of previtellogenic and vitellogenic oocytes (Fig. 2d). The immunohistochemical detection of $17-\beta$ estradiol revealed the presence of this hormone in the follicular cells and connective theca in both previtellogenic and vitellogenic stages (Figs. 2e,f).

\section{DISCUSSION}

The histological study of both male and female reproductive organs of $B$. mauritanicus showed that spermatogenesis, oogenesis and folliculogenesis were continuous, and comparable to the ones observed in most African anurans. Like other amphibians, steroid hormones were found in the follicle wall (FERnANDEZ \& Ramos, 2003).

In several African anurans (B. regularis, P. maccarthyensis, $P$. oxyrhynchus, $P$. calcaratus or $X$. laevis), sexual cycles are continuous in



Figure 1: Cross sections of Bufo mauritanicus testis. (a) All the spermatogenetic categories are present. FS: Spermatozoa fascia, LTS: Lumen of the seminiferous tube, SP: Spermatid. Bar $=50 \mu \mathrm{m}$.

(b) Detection of lipids on frozen sections stained with Sudan black. CL: Leydig-like cells, FS: Spermatozoa fascia. Bar $=50 \mu \mathrm{m}$. 



Figure 2: Cross sections of Bufo mauritanicus ovary. (a) Cross section of B. mauritanicus ovary showing previtellogeic follicles. C: cytoplasm, N: nucleus, n: nucleoli, St Ia: stage Ia follicle, St II: stage II follicle, TC: connective theca. (b) B. mauritanicus ovary showing vitellogenic follicles. St IVa: oocyte in early vitellogenesis, St V: oocyte at the end of vitellogenesis. (c) Presence of PAS positive material in the cortical part of the vitellogenic oocytes and mucopolysaccharidic nature of vitellin membrane (mv). (d) Detection of lipids on frozen sections stained with black Sudan. L: Lipids, VO: Vitellogenic oocyte. (e) Immunohistochemical detection of $17 \beta$-estradiol in follicles, during previtellogenesis. St. II: stage II follicle. The arrow indicates the presence of labelled follicle cells. (f) Immunohistochemical detection of $17 \beta$-estradiol in follicles during vitellogenesis. The arrow indicates the presence of labelled follicle cells. Bar $=50 \mu \mathrm{m}$. 
both males and females (DumONT, 1972; Delsol et al., 1980, 1981, 1995; GUEYDANBACONNIER, 1980; GUEYDAN-BACONNIER $e t$ al., 1984a,b; PUjOL, 1985; HaUSSEN \& Riebesell, 1991; Pujol \& Exbrayat, 1996, 2000, 2001; EXBRAYAT et al., 1998; SancheZ \& Villecco, 2003; Du PreEZ et al., 2005; VAN WYK et al., 2005). A continuous reproductive cycle has also been observed in the African caecilian Boulengerula taitanus living in Kenya (MEASEY et al., 2008). In the viviparous toad $N$. occidentalis living in Nimba Mount, Guinea, sexual cycles are discontinuous in males (GAVAUD, 1976, 1977) as well as in females (LAMOTTE \& TUCHMANDuplessis, 1948; LAMOTTE et al., 1964, XAVIER, 1986).

Our results extent the results found in males of $B$. mauritanicus by KISSERLI \& EXBRAYAT (2006) to females regarding to the continuous nature of the reproductive cycle of this species. In several African toads including B. mauritanicus, gonads are ready to produce germ cells when external conditions are favourable. In African toads living in semi-arid areas, reproduction is narrowly linked to rainfalls coupled with a brutal decrease of temperature (GUILLON et al., 2004). Only in $N$. occidentalis and other member of genus Nectophrynoides (XAVIER, 1986), sexual cycles are discontinuous. This fact is certainly related to viviparity or ovoviviparity, modes of reproduction protecting embryos from external conditions during their development. Reproduction of B. mauritanicus depends on local climate (SCHLEICH et al., 1996) and breeding is observed when rain falls down. When precipitations are insufficient, reproduction does not occur during several successive years (SCHLEICH et al.,
1996). This situation can be compared to that of $B$. regularis. When this species is living in a semi-arid area, it is ready to breed throughout the year, rainfall being the releasing factor of breeding (PUJOL, 1985; PUJOL \& EXBRAYAT, 1996, 2001). So, reproduction of $B$. mauritanicus is an additional example of adaptation to seasonal variations in an African amphibian.

\section{REFERENCES}

Bons, J. \& Geniez, P. (1996). Amphibiens et Reptiles du Maroc (Sahara Occidental Compris). Atlas Biogéographique. Asociación Herpetológica Española, Barcelona.

Delsol, M.; Gueydan-Baconnier, M.; Neyrand de Leffemberg, F. \& Pujol, P. (1980). Cycle spermatogénétique continu chez des Batraciens tropicaux. Bulletin de la Société Zoologique de France 105: 232-233.

Delsol, M.; Flatin, J.; Gueydan-Baconnier, M.; Neyrand de Leffemberg, F. \& Pujol, P. (1981). Action des facteurs externes sur les cycles de reproduction chez les Batraciens. Bulletin de la Société Zoologique de France 106: 419-431.

Delsol, M.; Blond-Fayolle, C. \& Flatin, J. (1995). Appareil génital mâle, anatomie, histologie, déterminisme du cycle sexuel, In P.P. Grassé \& M. Delsol (eds.) Traité de Zoologie tome XIV, fasc. 1-A, Masson, Paris, pp. 1187-1229.

Dumont, J.N. (1972). Oogenesis in Xenopus laevis (Daudin). I. Stages of oocyte development in laboratory maintained animals. Journal of Morphology 136: 153-180.

Du Preez, L.H.; Everson, G.J.; Hecker, M.; CarR, J.A.; GIEsY, J.P.; Kendall, R.J.; SMITH, E.E.; VAN DER KRAAK, G. \& 
SALOMON, K.R. (2005). Seasonal changes in testicular morphology in the african clawed frog, Xenopus laevis: a histometric analysis. 5th World Congress of Herpetology, Stellenbosch, South Africa, Abstracts: 42.

EXBRAYAT, J.-M. (2001). Genome Visualization

by Classic Methods in Light Microscopy. CRC Press, Boca Raton, London, New York, Washington, D.C.

Exbrayat, J.-M.; Pujol, P. \& Leclerce, B. (1998). Quelques aspects des cycles sexuels et nycthéméraux chez les amphibiens. Bulletin de la Société Zoologique de France 12: 113-124.

FernandeZ, S.N. \& Ramos, I. (2003). Endocrinology of reproduction, In B.G.M. Jamieson (ed.) Reproductive Biology and Phylogeny of Anura. Science Publishers, Inc., Enfield, pp. 73-117.

GAVAUD, J. (1976). La gamétogenèse du mâle de Nectophrynoides occidentalis Angel (Amphibien Anoure vivipare). I. Etude quantitative au cours du cycle annuel chez l'adulte. Annales de Biologie Animale, Biochimie et Biophysique 16: 1-12.

GaVAud, J. (1977). La gamétogenèse du mâle de Nectophrynoides occidentalis Angel (Amphibien Anoure vivipare). II. Etude expérimentale du rôle des facteurs externes sur la spermatogenèse de l'adulte, au cours du cycle annuel. Annales de Biologie Animale, Biochimie et Biophysique 17: 679-694.

GUEYDAN-BACONNIER, M. (1980). Le cycle sexuel chez les mâles et les femelles de Phrynobatrachus calcaratus (Peters, 1863) Batracien Anoure tropical. Ph.D. Dissertation, University of Paris VI, Paris. Gueydan-Baconnier, M.; Neyrand DE Leffemberg, F. \& Pujol, P. (1984a). Comparaison de la vitesse spermatogéné- tique entre trois batraciens tropicaux. Bulletin de la Société Herpétologique de France 29: 69-70.

Gueydan-Baconnier, M.; Neyrand DE Leffemberg, F.; Pujol, P.; Delsol, M. \& Flatin, J. (1984b). Etude comparative du dynamisme de la spermatogenèse chez trois Batraciens tropicaux par autoradiographie. Annales de Sciences Naturelles Zoologie, 13 ime série 6: 191-196.

Guillon, M.; Le Liard, G. \& Slimani, T. (2004). Nouvelles données sur la répartition et l'écologie de la reproduction de Bufo brongersmai, $B$. viridis et $B$. mauritanicus (Anura, Bufonidae) dans les Jbilets centrales (Maroc). Bulletin de la Société Herpétologique de France 111: 37-48.

Hausen, P. \& Riebesell, M. (1991). The Early Development of Xenopus laevis. An Atlas of the Histology. Springer-Verlag, New York.

Kisserli, O. \& Exbrayat, J.M. (2006). Premières données sur le cycle de reproduction des mâles de Bufo mauritanicus (Schlegel, 1841) dans la zone humide de Beni-Belaid (Jijel, Algérie). Bulletin de la Société Herpétologique de France 120: 5-13.

Lamotte, M. \& Tuchmann-Duplessis, $\mathrm{H}$. (1948). Structure et transformations gravidiques du tractus génital femelle chez un Anoure vivipare (Nectophrynoides occidentalis Angel). Comptes Rendus de l'Académie des Sciences de Paris 226: 597-599.

Lamotte, M.; Rey, P. \& Vogeli, M. (1964). Recherches sur l'ovaire de Nectophrynoides occidentalis, Batracien anoure vivipare. Archives d'Anatomie, de Microscopie et de Morphologie 5: 315-340.

Martoja, R. \& Martoja, M. (1967). Initiation aux Techniques de l'Histologie Animale. Masson, Paris. 
Measey, G.J., Smita, M., Beyo, R.S. \& Oommen, O.V. (2008). Year-round spermatogenic activity in an oviparous subterranean caecilian, Boulengerula taitanus Loveridge 1935 (Amphibia Gymnophiona Caeciliidae). Tropical Zoology 21: 109-122.

NeyRAND DE LefFEMBERG, F. \& EXbRAyat, J.M. (1995). Etude comparative du dynamisme de la spermatogenèse chez les Amphibiens par la méthode histoautoradiographique à la thymidine tritiée. Bulletin de la Société Linnéenne de Lyon 64: 356-372. Pujol, P. (1985). Quelques Aspects de la Reproduction du Crapand Bufo regularis Reuss, 1834. Diplôme de l'E.P.H.E., Lyon.

Pujol, P. \& EXBRAYAT, J.M. (1996). Variations du tissu interstitiel du testicule et de l'hypophyse chez Bufo regularis mâle au cours du cycle sexuel. Bulletin de la Société Herpétologique de France 80: 27-37.

Pujol, P. \& EXbrayat, J.M. (2000). Mise en évidence de l'homogénéité des testicules multilobés de deux amphibiens par des méthodes morphométriques. Bulletin de la Société Herpétologique de France 95: 43-56.
Pujol, P. \& Exbrayat, J.M. (2001). Quelques aspects de la biologie de la reproduction et des cycles sexuels chez Bufo regularis Reuss (1834), amphibien anoure. Bulletin Mensuel de la Société Linnéenne de Lyon 71: 12-52.

SANCHEZ, S.S. \& VIlleCCCO, F.I. (2003). Oogenesis. In B.G.M Jamieson (ed.) Reproductive Biology and phylogeny of Anura. Science Publishers, Inc, Enfield, pp. 27-71. Schleich, H., Kästle, W. \& Kabishi, K. (1996). Amphibians and reptiles of North Africa, Koltz Scientific Book, Keonigstein, Germany.

Van WyK, J.H.; Hurter, E.; PoOl.; E.J. \& LESLIE, A.J. (2005). Seasonal variation in reproductive activity in natural Xenopus laevis populations in the Western Cape Province, South Africa. 5th World Congress of Herpetology, Stellenbosch, South Africa. Abstracts: 103.

XAVIER, F. (1986). La reproduction des Nectophrynoides, In P.P. Grassé \& M. Delsol (eds.) Traité de Zoologie tome XIV, fasc. 1-B, Masson, Paris, pp. 497-513. 